\title{
事業所・企業統計を用いた地方都市への支社配置の分析* Analysis of Branch Office Structure by the Establishment and Enterprise Census*
}

\author{
塚井 誠人 ${ }^{\dagger}$ ・奥村 誠 \\ By Makoto TSUKAI ${ }^{\dagger}$ and Makoto OKUMURA ${ }^{\dagger}$
}

1. はじめに

「札仙広福」などの地方中核都市の業務拠点の多 くは，東京や大阪の本社の管轄を受ける「支店」で あり，その都市だけでなく周辺の都市にサービスし ながら本社との業務情報交流を中継する役割を果た してきた. 90 年以降，地方中核都市から「支店」が 撤退する例が報告され，「支店経済」の崩壊による地 方都市の沈滞が懸念されるようになった。これを受 けて，新産業の育成等による支店経済依存からの脱 却策が議論されたが，それらは支店撤退に対する対 症療法に留まっており，広域的な業務ネットワーク の変化を踏まえた上で, 行政として地域経済の核と なる「支店」を維持するか，または支店経済からの 脱却を図るべきなのか, という基本方針に関する検 討はほとんどなされていない.

規模の大きな都市に業務拠点を集約する「中抜き」 や「支店」の撤退は，企業にとっては効率的な業務 ネットワークへの移行を図るための適応的変化と思 われる. 企業の業務拠点配置は，人件費を含む拠点 配置費用や地域間交流費用などのコス卜要因, 商物 分離や管理業務の集約化やバーチャルショップといっ た業務展開戦略のほか, 中期的な景気動向などの要 因に左右される.

これらの要因のうち, 地域間交流費用は代表的な 政策変数である. 政策担当者が高速交通網の整備や 通信網の導入によって地域間交流費用を低下させる と, 企業はその変化に対応した効率的な業務ネット ワークを形成する．しかしこれは短期的な変化であ る. 中期的には，企業は低下した地域間交流費用を 前提として人員配置を見直したり, 新しい情報通信 設備を導入するなどの方策をとりつつ, 管理業務の 集約化を進めることによって, 業務ネットワーク機 能の見直しを行う可能性がある.

90 年代は, 都市間交通網の充実と平行して, IT 技

\footnotetext{
${ }^{*}$ Key words : 地域計画，システム分析，国土計画

†正会員, 博 (工), 立命館大学理工学部

(テ525-0071 草津市野路東 1-1-1, TEL\&FAX 077-565-5786)

正会員, 博 (工), 広島大学大学院工学研究科

（甬739-8527 東広島市鏡山 1-4-1, TEL\&FAX 082-424-7826)
}

術の導入が急速に進んだ時期にあたる．上記のよう な管理業務の集約化に関しては，労働生産性の向上 の観点から，ホワイトカラー従業者一人当たりの交 通・通信資本装備率と労働生産性の関係を分析する アプローチがとられてきた ${ }^{1)}$.しかしそのような研 究では, 企業の業務ネットワーク構造, つまり業務 活動の空間要素は捨象される.また企業の業務ネッ トワークに関する既存研究は, 簡単な集計分析や仮 想的な 2〜3都市空間上での理論分析に限られる 2)3). したがって，地方企業の今後の産業政策を考える上 では管理業務の集約化等の中期的な影響に関する実 証分析が強く求められる.

本研究は, 平成 3 年と 13 年の事業所・企業統計調 查 ${ }^{4)}$ から得られる本所支所間の管轄/被管轄関係の データを用い，その空間構造を分析して，企業の業 務ネットワークの構造を明らかにする．さらに得ら れた業務ネットワークの空間構造と, 各管轄関係の 下で雇用されている従業者数の関係について分析を 行う。その上で得られた知見を踏まえて，地方都市 の「支店維持」政策について考察を行う。なお以下 の分析では，対象企業の業種を限定せず，空間的な 管轄／被管轄構造が類似した企業群は, 同じタイプ の「業務ネットワーク」を有する企業と考える.

\section{2. 事業所・企業統計調查における管轄関係}

\section{(1) 事業所数・従業者数の集計分析}

総務庁統計局が 5 年おきに実施する企業事業所統 計調查 (以下事統)においては都道府県に存在する民 営事業所を本所, 支所, および単独事業所に区分し, 支所についてはその本所の所在する都道府県ごとに 細分類して, 事業所数と従業者数が公表されている. 本所支所別の事業所/従業者構成比を図 1 に示す. 平 成 3 年/平成 13 年の総事業所数は, それぞれ約 250 万力所/約 266 万力所（伸び率約 6.6\%）, 同総従業 者数はそれぞれ約 3989 万人/約 4055 万人（伸び率 約 $1.7 \%$ ）であった．事業所数ベースでは単独，支所 (同一都道府県本所)，支所（他都道府県本所），本 所の順に構成比が高いが, 従業者数ベースでは平成 


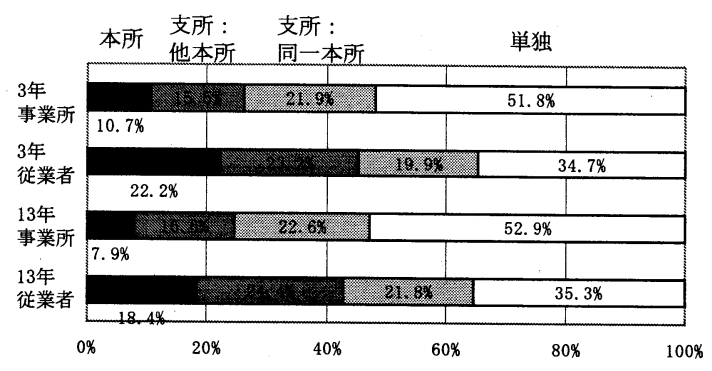

図 1 本所支所別事業所/従業者構成比

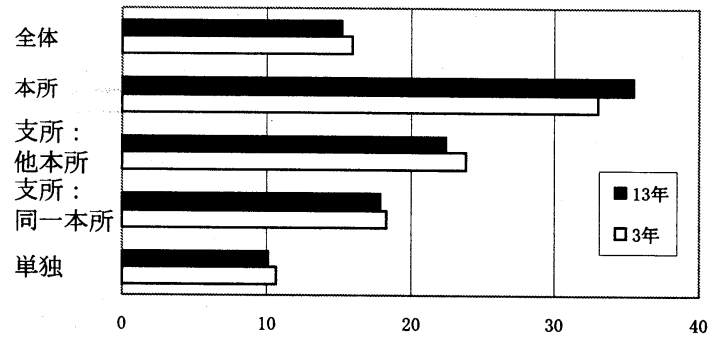

図 2 本所支所別平均従業者数

3 年では, 単独, 支所（他都道府県本所）, 本所, 支 所 (同一都道府県本所) の順に, 平成 13 年では, 単 独, 支所 (他都道府県本所), 支所 (同一都道府県 本所）, 本所の順に構成比が高い. 平成 3 年と平成 13 年を比較すると, 事業所数, 従業者数とも本所の 構成比の低下が著しく, その他の構成比は微増して いる.

本所支所別の事業所あたりの従業者数は図 2 に示 すとおりであり, 広域で業務展開している事業所ほ ど規模が大きい. 平成 3 年と平成 13 年を比較する と, 本所（約 33.0 人から約 35.5 人に増加）を除い て事業所の規模は縮小し, 全体平均は約 16.0 人から 約 15.2 人に減少している. 特に支所（他都道府県本 所）は約 23.8 人から約 22.4 人に減少している.

以上をまとめると, 本所数は減少しつつその規模 は拡大する一方で, 支所の規模は縮小される傾向が 窥える。

\section{(2) 事統における支所の位置づけ}

冒頭に述べたような企業の広域的な支社配置の把 握のためには, 事統データのうち「本所の都道府県 ごとの支所の事業所数」の統計が有用であるが, こ の支所（他都道府県本所）には異なるタイプのもの が含まれている、ひとつは「○○商事中国支社」の ように当該の都道府県だけでなくその周辺の都道府 県を含めて業務を行うような広域的な「支社」であ り，もうひとつは「○○銀行広島駅前支店」のよう

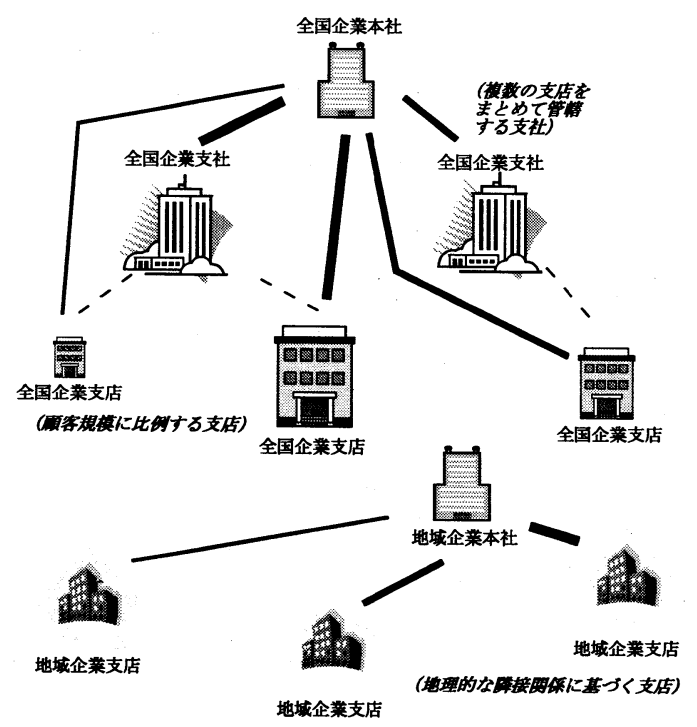

図 3 全国企業の支社，支店，地域企業の支店

にその業務の領域が狭く当該都道府県内部に納まる ような地域的な「支店」である。本研究の目的を踏 まえれば，前者の広域的な支社の立地数を把握する 必要がある.

シダールは，地域全体の小売業従業人口に対する 卸売従業人口の比率を用い, 都市の卸売業を, 当該 都市内部にサービスする部分と他都市に広域的にサー ビスする部分に分割し，後者によって都市の中心性 を計測する方法を提案した ${ }^{5)}$ 。ここでは同様のアイ デアを用いて広域的な支社を分離する，すなわち全 国的に業務を展開する企業（以下全国企業と呼ぶ） の顧客の分布は,ほぼ各都道府県の総従業者数（全 国展開していない企業の従業者も含む) に比例する と仮定する.ここで人口ではなく総従業者数を用い るのは，広域的な支社配置はメンテナンスや小売り などの即時的な対応を要求される個人ではなく, 企 業向けの専門的なサービスを提供するような業務ネ ットワークに支配されていると考えたためである。

全国企業は, 各都道府県ごとに一定の顧客数に対 応するように「支店」を設置し，さらにそれらの「支 店」と「本社」との連絡を円滑化するために少数の 都道府県を選んで「支社」を設置すると仮定すれば, 事統支所数のうち当該都道府県の総従業者数に比例 する部分が「支店」であり，残余の部分を「支社」と 考えることができる.

実際には，すべての企業が全国的に業務を展開し ているわけではない. 電力会社のように, 地理的に 隣接する都道府県を営業エリアとする企業 (以下, 地 域企業と呼ぶ）が存在し, その支店が本社とは異な 
る府県に設置されるケースが多く見られる. 事統に おける支所（他都道府県本所）にはこのような地域 企業の「支店」が含まれていることに注意する必要 がある. 地域企業の支社配置は, 歴史的, 地理的な 隣接関係に基づいており，全国企業に比べればより 安定的であると考えられる.

全国企業の支社, 全国企業の支店, 地域企業の支 店の関係を図 3 に示す. 全国企業には, 1) いくつか の地域をまとめて管轄する本社一支社 (一顧客) 構 造, 2) 地域の顧客数に比例して管轄する本社一支店 （一顧客）構造の 2 種類がある, また, 地域企業は地 理的な隣接関係に基づく本社一支店構造をとる.こ れらの管轄関係は図中の実線で示す部分であり, 事 統にはこれら 3 種類の合計值が分離されずに記録さ れていると考える.

\section{3. 管轄モデルと従業者モデルの定式化}

本節では事統の支所（他都道府県本所）の管轄／ 被管轄数を，(1）全国企業の支社配置モデルによる 本社一支社関係，(2) 各都道府県の従業者数に比例 して本社都道府県との間に形成される全国企業の本 社一支店関係，(3) 地理的な近接関係に基づいて形 成される地域企業の本社一支店関係の 3 種類に分解 するための管轄モデルを提案する. さらに, 得られ た 3 種類の管轄関係と, 事統において支所 (他都道 府県本所）の管轄／被管轄数と共に記録されている 従業者数 (以下, 管轄従業者数) の関係について, 従 業者モデルによって分析を行う.

\section{(1) 全国企業の支社配置モデル}

全国企業は沖縄を除く全国 46 都市を管轄範囲と し, 本社一複数支社 -46 都市の支店・顧客から成る 業務ネットワークを費用を最小とするように展開す ると考える. 著者らの先行研究 6)により, 全国企業 の支社配置は本社都市 $k$, 交流比 $R_{l}$ を与件とする総 コスト $Z^{k l}$ の最小化問題として以下のように定式化 できる.

$$
\begin{aligned}
& Z^{k l}=\min \sum_{i \in I} \sum_{j \in J} C_{i j} W_{i} x_{i j}^{k l} \\
& \quad+R_{l} \sum_{j \in J} C_{j k} \sum_{i \in I} W_{i} x_{i j}^{k l}+\sum_{j \in J} F_{j} y_{j}^{k l}+D_{k}
\end{aligned}
$$

$y_{j}, x_{i j}$ は操作変数であり, それぞれ候補都市 $j$ への 支社配置と, $j$ 支社が管轄する顧客都市 $i$ の関係を 表わすダミー変数である. $W_{i}$ は都市 $i$ の総従業者数 である. $R_{l}\left(0<R_{l}<1\right)$ は支社の機能の高さを示す パラメータ (交流比) である. $R_{l}$ が 0 に近いとき, 配 置される支社において顧客からの情報の大部分が圧
縮されるためその支社機能は高く, $R_{l}$ が 1 に近いと きは支社機能が低い状態を表わしている. なお $R_{l}$ の 添字 $l$ は, $R_{1}=0.1(l=1), R_{2}=0.2(l=2), \ldots$ のよ うに, 離散化した交流比 $R_{l}$ を表わしている. 式 (1) を $C_{i j}$ は都市 $i j$ 間の単位一般化交通費用, $F_{j}$ は都市 $j$ 一の支社立地費用, $D_{k}$ は都市 $k$ への本社立地費用 である. 制約条件は以下の通りである.

$$
\begin{array}{ll}
\sum_{j \in J} x_{i j}^{k l}=1 & \forall i \in I \\
x_{i j}^{k l} \leq y_{i}^{k l} & \forall i \in I, \forall j \in J \\
x_{i j}^{k l} \in\{0,1\} & \forall i \in I, \forall j \in J \\
y_{j}^{k l} \in\{0,1\} & \forall j \in J
\end{array}
$$

\section{（2）全国企業の支店配置}

先述したシダールの考え方に従い，全国企業は各 都市の総従業者数に比例して支店を配置する.

$$
M_{k j}=\gamma_{k} W_{j}
$$

$M_{k j}$ は都市が $k$ に本社を置く全国企業が都市 $j$ に置 く支店数, $W_{j}$ は都市 $j$ の総従業者数, $\gamma_{k}$ は比例定数 である.

\section{(3) 地域企業の支店配置}

地域企業の業務ネットワークは地理的な条件に規 定されていることから, 重力モデルにより表現する.

$$
L_{k j}=A P_{k}^{\alpha_{1}} P_{j}^{\alpha_{2}} C_{k j}^{\psi}
$$

$L_{k j}$ は都市 $k$ に本社を置く地域企業の都市 $j$ における 支店数である. $P_{k}, P_{j}$ は，それぞれ都市 $k, j$ の総 従業者数, $C_{\mathrm{k} j}$ は都市 $k j$ 間の一般化交通費用， $\alpha_{1}$, $\alpha_{2}, \psi, A$ はパラメータである.

\section{(4) 管轄数の観測}

本所が $k$ にある企業の，都道府県 $j$ への管轄数の 観測值 $S_{k j}$ は, 全国企業の支社による管轄数 $N_{j}^{k l}$, 支 店による管轄数 $M_{k j}$, 地域企業の支店による管轄数 $L_{k j}$ とが重ねあわされたものである.

$$
\begin{aligned}
& S_{k j}=\sum_{l} \beta^{k l} N_{j}^{k l}+M_{k j}+L_{k j}+\epsilon_{k j} \\
& N_{j}^{k l}=\sum_{i} W_{i} x_{i j}^{k l}
\end{aligned}
$$

$N_{j}^{k l}$ はタイプlの本社が $j$ に設置する支社数であり, 式（9）に示すように，その数は支社 $j$ の管轄下に ある顧客数の和に比例すると考える. $\beta^{k l}$ はタイプ $l$ の全国企業の構成比を表すパラメータである．また $\epsilon_{k j}$ は, 本研究で想定していないタイプの業務ネット ワークに対応する誤差項である. 
式 (6)，(7)，(8) の管轄モデルを，誤差 $\epsilon_{k j}$ を最小 化するように非線形回帰分析によって推定し，パラ メータ $\alpha_{1}, \alpha_{2}, \psi, A, \gamma_{k}, \beta^{k l}$ を同時推定すること により，全国企業の支社，支店による管轄数，およ び地域企業による管轄数を求めることとする．なお， 扱うデータが空間的な属性を有する以上, 空間構造 を考慮した空間統計的な分析手法を適用するほうが 妥当であるが，事前に誤差の空間構造を明示的に考 慮することが困難であるので，本研究では，誤差を 独立と考えて通常の非線形回帰分析を適用した.

\section{(5) 従業者数の観測}

本所が $k$ の企業が，都道府県 $j$ で雇用している管 轄従業者数の観測値 $E_{k j}$ は, 上記の 3 種類の企業に よるものである.そこで管轄モデルから得られるパ ラメータ推定值に基づいて, 都道府県間ごとに 3 種 類の企業による管轄数の推計值を求め, これらに $E_{k j}$ を回帰する. タイプ $l$ の全国企業の管轄数の推計值 を $\hat{N}_{k j}^{l}=\hat{\beta}^{k l} N_{j}^{k l}$, 地域企業の管轄数の推計值を $\hat{M}_{k j}$, 地域企業の支店数を $\hat{L}_{k j}$ とすれば，従業者モデルは 以下のように定式化することができる.

$$
E_{k j}=\sum_{l} \eta^{l} \hat{N}_{j}^{k l}+\lambda \hat{M}_{k j}+\mu \hat{L}_{k j}
$$

ここで $\eta^{l}$ は管轄対象顧客一人当たりの従業者数, $\lambda$, $\mu$ は, 全国企業, 地域企業 1 支店当たりの平均従業 者数を表わすパラメータである. さらに都市 $j$ に立 地する支社が管轄対象とする顧客数 $\hat{C} u_{j}^{k l}$ について, 仮定により $\hat{C} u_{j}^{k l}=\hat{N}_{j}^{k l} / R_{l}$ と表わされることに注意す ると, 式（10）は以下のように改めることができる。

$$
\begin{aligned}
E_{k j} & =\sum_{l} \eta^{l} \hat{C} u_{j}^{k l}+\lambda \hat{M}_{k j}+\mu \hat{L}_{k j}+\varepsilon_{k j} \\
\eta^{l} & =\rho R_{l}^{\omega}
\end{aligned}
$$

式（11）の従業者モデルを誤差 $\varepsilon_{k j}$ を最小化するよ うに非線形回帰分析によって推定する．ただしパラ メータ $\eta^{l}$ については, 全ての $R_{l}$ に対応する業務ネッ トワーク $\hat{N}_{j}^{k l}$ が管轄モデルの推計から得られるとは 限らない，そこで，式（12）に示すようにパラメー 夕 $\rho, \omega$ を持つ $R_{l}$ の連続的な関数として定義して, 安定した推計結果が得られるようにする.

\section{4. 分析結果}

\section{(1) 管轄モデルの推定結果と考察}

一般化交通費用 $C_{i j}$ は, 全国の都道府県庁所在地 間の鉄道・航空の所要時間データベースであるトラ ネットシステムから得られる費用を用いて ${ }^{7)}$, 時間 価值を 4500 円 /時間として, 都道府県間純流動デー
タの鉄道・航空分担率により加重平均して計算した. また本社, 支社配置コスト $F_{j}, D_{k}$ は, 実際のオフィ ス賃料に基づいて值を設定した．全国企業の本社都 市 $k$ は, 事統で本所の多い上位 12 都市（宮城, 埼玉, 千葉, 東京, 神奈川, 静岡, 愛知, 京都, 大阪, 兵 庫, 広島, 福岡）として, それぞれ 9 種類の $R_{l}$ につ いての合計 108 通りの支社配置パターンの中で, 現 況の支所分布に対して当てはまりの良い組み合わせ を求めた.

管轄モデルの推定結果を表 1 に示す．決定係数は 平成 3 年, 平成 13 年とも 0.9 以上となり, 適合度 は高い. 宮城本社と愛知本社の業務ネットワークは, 有意なパラメータが得られなかったため除外した.こ の理由として, 宮城本社は全国展開する企業が少な いためと思われる. 愛知本社は地理的に日本の中心 に位置するため, 地域企業の業務ネットワークと類 似した空間構造となって, 全国企業の業務ネットワー クとして推定できなかった可能性がある.

地域企業のパラメータのうち, 総従業人口 (本社 都市) は平成 13 年では有意となり, その影響は強く なっている. 一方, 総従業人口. (支店都市) は負の推 定值となっている. これは総従業人口の多い都道府 県には独自の企業が立地する可能性が高いため, 他 の都道府県に本社を置く地域企業が支店を設置する ことが少ないことを意味する.

支社機能の指標である $R_{l}$ に着目すると, 東京本社 と大阪本社の全国企業では, 平成 3 年よりも低い $R_{l}$ と高い $R_{l}$ の両方が平成 13 年に表われており, 両都 市ともより支社機能の低い方 $\left(R_{l}\right.$ が高い方) のシェ アが高くなっている. また広島や福岡の $R_{l}$ も若干高 くなっている.

全国企業の本社構成比は, 高い順に東京, 大阪, 神 奈川, 兵庫, 埼玉, 京都‥となった. 全国企業の支 社のシェアについて, 平成 3 年と平成 13 年を比較 すると, 東京は 0.3 ポイント上昇しており $(17.3 \% \rightarrow$ 17.6\%），各地に支社を配置するタイプの全国企業 の本社機能は, 東京都心に回帰する傾向が見られる. 一方全国企業の支店については, 関東圏（埼玉，千 葉, 東京, 神奈川）全体では 7.9 ポイント低下して いる $(34.5 \% \rightarrow 26.6 \%)$. 関西では，大阪の全国企業 の支社のシェアは 0.2 ポイント低下しており (3.4\% $\rightarrow 3.2 \%$ ），全国企業の支店については関西圈（京 都, 大阪，兵庫）全体で 1.0 ポイントの低下が見ら れた $(12.1 \% \rightarrow 11.1 \%)$ 。また福岡は全国企業の支社 のシェアは, 東京と並んで 0.4 ポイント上昇してい る $(0.8 \% \rightarrow 1.2 \%)$,

次に推計されたパラメータと式（8）に基づいて, 各都道府県の支所への管轄を, 全国企業 (本社所在 
表 1 管轄モデルの推定結果

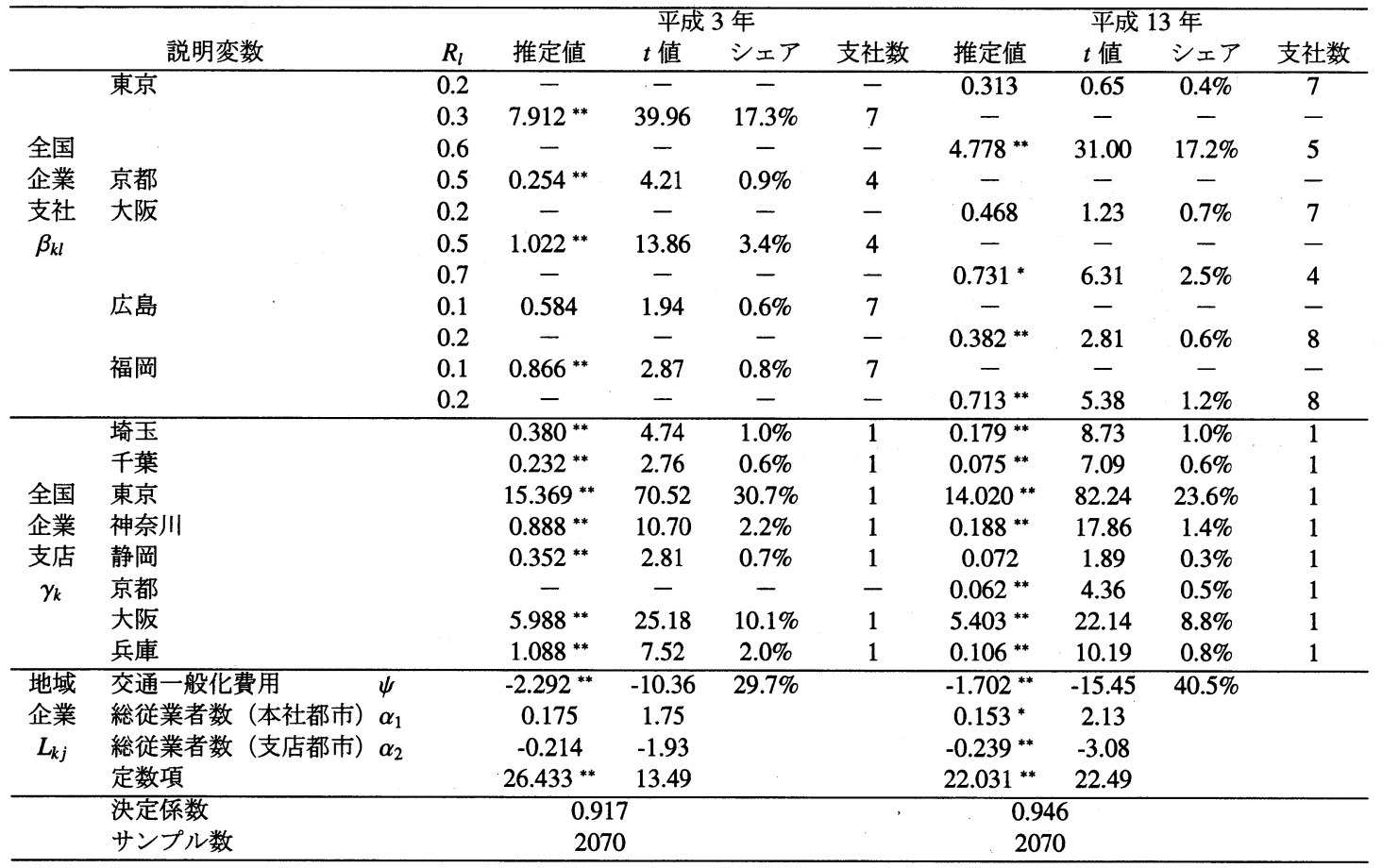

** $: 1 \%$ 有意, * : $5 \%$ 有意

地別)の支社と支店への管轄（式（8）の第 1 項と第 2 項の和）および地域企業による支店への管轄（式 （8）の第 3 項）に分解して, 総管轄数に対して本社 所在地別の全国企業, 地域企業の管轄数の構成比を 図 4, 図 5 に示す. 平成 3 年と平成 11 年を比較する と，埼玉，福岡に本社をおく企業以外の全国企業の 構成比は低下する一方で, 地域企業の構成比が上昇 していることがわかる.

\section{(2) 従業者モデルの推定結果と考察}

従業者モデルの推定結果を表 2 に示す. 決定係数 は平成 3 年, 平成 13 年とも 0.98 程度となりモデル の適合度は高く, またパラメータの有意水準も, 全 て高い結果が得られた。

式（12）より，推定された $\rho ， \omega に$ 基づいて，管 轄対象顧客 1 人あたりで必要な支社従業者数 $\eta^{l}$ を計 算した結果を図 6 に示す $\left(\eta^{l}=\partial E_{k j} / \partial C u_{j}^{k l}\right)$. 平成 3 年/平成 13 年とも支社機能が高くなると（Rl が 小さくなると）, 顧客 1 人あたりの従業者数は减少 する. 平成 3 年と平成 13 年のプロットを比較する と, $R_{l}$ が 0.7 以下まで支社機能が高くなると, 顧客 1 人あたりの従業者数は, 平成 13 年の方が少なくな る. 管轄モデルの推定結果からは $R_{l}$ が 0.7 以下の業 務ネットワークパターンが得られており，この範囲
では $\eta^{l}$ は内挿されているため, 推定結果の信頼性は 高いと思われる.

パラメータ $\lambda, \mu$ は 1 支店あたりの従業者数を表 わしている. これらの平成 3 年と平成 13 年の推定 值を比較すると，全国企業の支店の従業者数は約 1 人少なくなっているのに対して，地域企業の従業者 数は約 1.3 人多くなっている.

管轄モデルと従業者モデルの結果をまとめると, 全 国企業では支社機能が低下していること，また仮に 支社機能が同水準であれば，全国企業の顧客一人当 たりの従業者数は少なくなっていることがわかった. また全国企業の支店では 1 支店あたりの従業者数は 減少し, 逆に地域企業では 1 支店あたりの従業者が 增加する傾向にある。

これらの結果に対しては, 次に示す 2 種類の考察 が成り立つ.すなわち，全国企業の業務の一部が地 域企業にアウトソーシングされるようになり，全国 企業が形成する固定的な本社一支社の業務ネットワー クの必要性が低下した可能性，または外国資本の導 入等によって海外との間で直接的に取引関係を結ぶ 企業が増加して国内全体で業務を行う必要が低下す る一方で，地域の中で行われる海外起因の業務が増 加したため, 地域企業によって雇用される従業員が 増加した可能性 (それぞれアウトソーシング仮説, グ 
48. $1 \%$

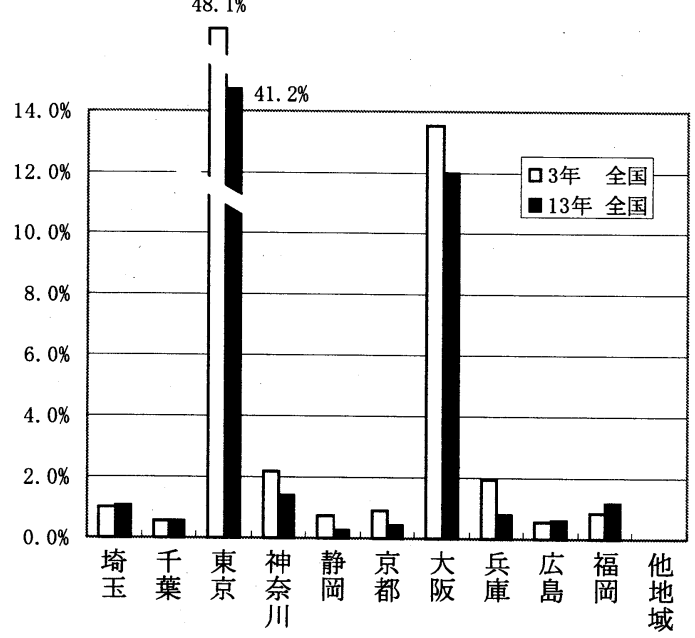

図4総管轄数に占める全国企業の構成比

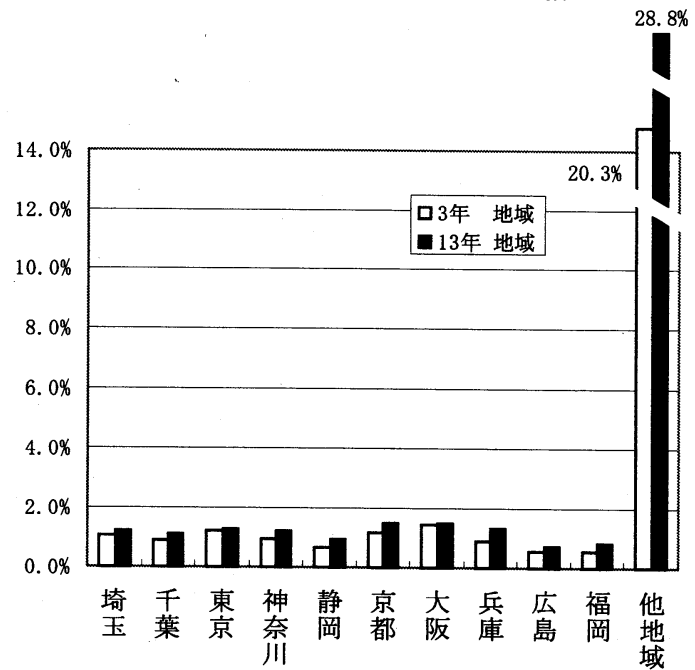

図 5 総管轄数に占める地域企業の構成比

ローバル化仮説）である.

いずれの仮説が正しいとしても，全体の管轄数に 占める全国企業の構成比が低下している以上, 今後 全国企業の支社, 支店の雇用力に期待することはで きないと思われる. したがって地方自治体にとって は, 地域の中で特色のある業務内容を有する地域企 業の育成を図る方が望ましいと考えられる。

\section{5. まとめ}

本研究は, 事業所·企業統計調査の本所支所間の管 轄/被管轄関係データに管轄モデルを適用して, 空 間構造の分析を行った. 分析の結果, 全国企業の本 社は東京周辺の都市からは减少し東京都内に回帰す る傾向と関西圈では全国企業の本社は微减する傾向
表 2 従業者モデルの推定結果

\begin{tabular}{|c|c|c|c|}
\hline パラメータ & 説明変数 & 平成 3 年 & 平成 13 年 \\
\hline \multirow[t]{2}{*}{$\rho$} & & $0.017^{* *}$ & $0.020^{* *}$ \\
\hline & 支社従業者数 & (13.90) & (10.17) \\
\hline$\omega$ & （全国企業） & $\begin{array}{l}1.169^{* *} \\
(19.03)\end{array}$ & $\begin{array}{l}1.694^{* *} \\
(9.00)\end{array}$ \\
\hline$\lambda$ & $\begin{array}{l}\text { 支店従業者数 } \\
\text { (全国企業) }\end{array}$ & $\begin{array}{c}26.758 * * \\
(195.67)\end{array}$ & $\begin{array}{c}25.849 * * \\
(184.36)\end{array}$ \\
\hline \multirow[t]{3}{*}{$\mu$} & $\begin{array}{l}\text { 支店従業者数 } \\
\text { (地域企業) }\end{array}$ & $\begin{array}{c}16.139 * * \\
(25.15)\end{array}$ & $\begin{array}{c}17.427^{* *} \\
(37.67)\end{array}$ \\
\hline & 係数 & 0.979 & 0.980 \\
\hline & プル数 & 2070 & 2070 \\
\hline
\end{tabular}

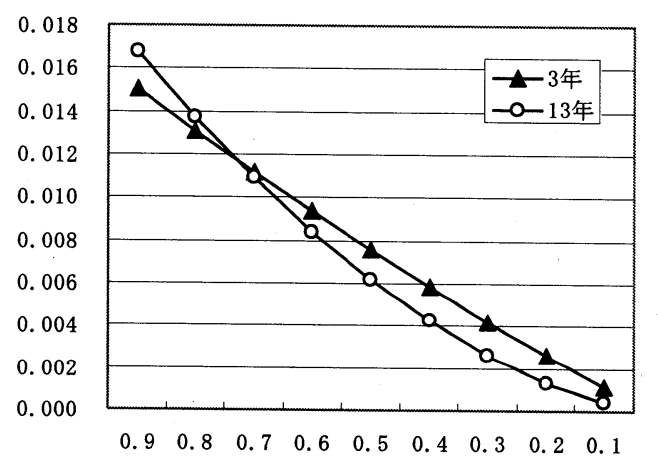

図 6 支社機能 $R_{l}$ とパラメータ $\eta^{l}$ の関係

が見られた. また全体的に, 支社機能は低下傾向に あることがわかった。

さらに同調査から得られる, 本所支所間の管轄／ 被管轄に関わる従業者数データについて, 管轄モデ ルから得られる 3 種類の企業による管轄情報を用い た回帰分析を適用したところ, 支社機能の水準が同 一であれば, 平成 13 年の方が全国企業では顧客一 人当たりの従業者数は減少する傾向にあることが明 らかとなった。

これらの結果は, 全国企業の業務の一部が各地域 の地域企業に分担されるアウトソーシングの可能性 や, 地域企業が海外から直接業務を受注していると いうグローバル化の可能性を示唆している.

また, 交通・通信インフラが高度化して都道府県間 の交流費用が低下する中で，全国企業の支社数減と 顧客一人当たりの従業者数は減少しており, その雇 用吸収力は低下していると判断できる.したがって, 今後「支店経済の維持」を目的とした政策の効果は 高くないと思われる. むしろ 1 支店当たりの従業員 数が増加している地域企業について, 特区制度等を 活用して国内の他地域との差別化を図り,グローバ ル化の流れに対応した地域政策をとることによって 
競争力を強化し，新しい企業を育成する政策の方が 有効と思われる.

今後は, 本研究で明らかとなった支社機能の低下 と, 顧客 1 人当たりの従業者数の減少傾向について, 交通・通信インフラ整備の変化との関連性を分析す る必要がある．また以上の分析手法の精緻化を図る ため, 空間統計学の手法を適用したモデル推計法を 開発する必要がある.

\section{参考文献}

1）熊坂有三, 峰滝和典 : IT エコノミーー情報通信技術はア メリカ経済をどう変えたかー，日本評論社，2001.
2) 埴淵知哉: 企業の空間組織から見た日本の都市システム, 人文地理, Vol.54, No.4, pp.71-86, 2002.

3) 文世一 : 都市間コミュニケーションとオフィス企業の支 店立地, 応用地域学研究, No.4, pp.77-88, 1999.

4) 総務庁統計局 : 平成 3 年事業所統計調査報告/平成 8 年 事業所・企業統計調查報告, 1993,1997.

5）大友篤：地域分析入門 [改訂版]，東洋経済新報社, p.97,1997.

6) 塚井誠人，奥村誠 : 本社支社配置の経年変化のモデル分 析, 都市計画論文集, No.36, pp.349-354, 2001.

7) 以下のホームページを参照のこと : http://www.mlit.go.jp/seisakutokatsu/soukou/navinet/tranet.htm

\section{事業所・企業統計を用いた地方都市への支社配置の分析*}

本研究は, 平成 3 年と 13 年の事業所・企業統計調査から得られる本所支所間の管轄/被管轄関係のデータを 用いて企業の業務ネットワークの空間構造を明らかにした．さらに，得られた業務ネットワークと各管轄関 係の下で雇用されている従業者数について分析を行い, 全国企業の従業者の顧客管理能力について経年比較 を行った. その結果, 全国企業の本社は東京周辺の都市では減少する一方で, 東京都内に回帰する傾向にあ ることが明らかとなった．さらに全国企業の従業者の顧客管理能力については，同一の支社機能水準で比較 した場合, 平成 13 年の方が全国企業の従業者 1 人当たりの顧客管理能力が高くなる傾向にあることが明ら かとなった.

\section{Analysis of Branch Office Structure by the Establishment and Enterprise Census*}

\section{By Makoto TSUKAI ${ }^{\dagger}$ and Makoto OKUMURA ${ }^{\ddagger}$}

This study compared the inter-city business network structure in 1991 and 2001, by using the establishment and enterprise census. In order to clarify the change in number of employees per customers, the relationship between employees on the inter-city business structure and estimated business network is analyzed and compared in 1991 and 2001. It was shown that the headquarters of nation-wide firms increased in Tokyo, but they decreased in the surrounding area. Further, the number of employees per customers in 2001 was fewer than that in 1991 at the identical branch function level. It means an employee in 2001 can supervise much number of customers than 1991. 